\title{
Plastic as substituent material for fine aggregate in concrete
}

\author{
Raju Suram $^{1}, T$.Srinivas ${ }^{2}$ and Vegiraju Naresh kumar Varma ${ }^{3}$ \\ ${ }^{1} \mathrm{M}$. Tech Scholar, GRIET, Hyderabad, India \\ ${ }^{2}$ Professor, GRIET, Hyderabad, India \\ ${ }^{3}$ Assistant Professor, GRIET, Hyderabad, India
}

\begin{abstract}
The Plastic is a part of our lives due to its daily usage. So, the consumption of plastic is increasing every year. The decomposition of plastic takes more than thousand years because of its non-biodegradable nature. The plastic harms the society and surrounding environment in all aspects. So, the best way to control the pollution posed by the plastic is recycling. The exponential growth in construction industry, the demand for natural aggregates increases but leads to depletion of natural resources. To overcome this issue plastic used as a fine aggregate replacement in concrete. The majority of the waste coming from the plastic bottles (Polyethylene Terephthalate) and food containers (Polypropylene). So, the recycled Polyethylene Terephthalate and Polypropylene used as a fine aggregate in concrete with percentages of $5 \%, 10 \%, 15 \%$. This paper objective is to assess the effect of Polyethylene Terephthalate and Polypropylene on compressive strength and workability. The workability and compressive strength of PET and PP have given good results up to $10 \%$ and $5 \%$. It has been observed from the test results that $5 \%$ and $10 \%$ is optimum for Polypropylene (PP) and Polyethylene Terephthalate (PET)as fine aggregate in concrete respectively.
\end{abstract}

\section{Introduction}

In the recent years, concrete manufactured globally Twenty-eight billion tons by every year. The concrete mix prepared by cement and natural aggregates. The construction industry consumed number of natural aggregates, cement. The excessive consumption of natural sand as a fine in concrete leads to sand mining. This results in land loss through river and reducing of water tables and also decreases the sediment supply. So, to reduce the use of sand in concrete to replace some alternate materials like robo sand and some waste materials. Among various waste materials, plastic waste is one of the major impacts on the environment because of its nonbiodegradability. In India 60 million tons of waste is disposed annually. The major waste coming from the domestic waste like daily used water bottles (Polyethylene terephthalate ${ }^{1}$ ), food containers (Polypropylene). The Polyethylene terephthalate and polypropylene disposal is very complex issue because low density and occupy large volume. So, the waste materials like Polyethylene terephthalate and Polypropylene are used as a fine aggregate in concrete, it acts as disposal of plastic and reduce the pollution caused by the plastic and also reduces use of sand in concrete.

This study is about the suitable substituent for concrete ingredient and to achieving a good environment. Trilok Gupta et.al., (2020) studied on strength and durability of concrete. The waste plastic asa replacement of fine with $0 \% 5 \% 10 \% 15 \%$ and $20 \%$. Observe compressive strength decreases beyond $15 \%$ of replacement of plastic with fine. Altamashuddinkhan Nandimalla et al (2019) studied on replacement of fine aggregate as polyethylene terephthalate. They reported as $5-10 \%$ replacement of fine as PET give good compressive strength. The required amount of plastic waste as fine in concrete improves the physical performance than normal concrete. M.B. Gaikwad et.al., (2019) studied on waste plastic. Waste plastic is used as a concrete ingrédient in the concrete mix. Beyond $15 \%$ of plastic replacement in the concrete reduces the compressive and tensile strength. Lokeshwari, M., et. al., (2019) investigated on pet and polypropylene as partial replacement in concrete as coarse and fine aggregate. From the results workability decreases with increment of plastic. The $10 \%$ and $20 \%$ replacement with

*Corresponding Author : srinu.tummala@gmail.com 
aggregate improves the behaviour of concrete. Beyond that it drastically decreases strength. Khatib et.al., (2019) studied on bottle caps. It replace with coarse aggregate. Concluded that an increasing and obtained maximum at $20 \%$. Also increases $16 \%$ compressive strength for replacement of $20 \%$.

\section{Polypropylene and Polyethylene Terephthalate}

\subsection{Polypropylene (PP)}

Polypropylene is widely used plastic with good properties, such as

- It has Chemical resistance

- It is inexpensive material

- It is resistant to moisture

Here used $<4 \mathrm{~mm}$ size of rounded shape particles

Table 1. Properties of Polypropylene (PP)

\begin{tabular}{|l|l|l|}
\hline Density & Melting Point & $\begin{array}{l}\text { Thermal } \\
\text { expansion }\end{array}$ \\
\hline $0.91-0.94 \mathrm{~g} / \mathrm{cm}^{3}$ & $160-166^{\circ} \mathrm{C}$ & $5.8-10 /{ }^{\circ} \mathrm{C}$ \\
\hline
\end{tabular}

\subsection{Polyethylene Terephthalate (PET)}

Polyethylene Terephthalate is mostly used plastic material obtained from the water bottles. It absorbs less water and good chemical resistance.

PET is

- highly flexible,

- good strength,

- $\quad$ Stiffness and ductility in its state.

Here used $<2 \mathrm{~mm}$ size of flaky particles.

Table 2. Properties of Polyethylene Terephthalate

\begin{tabular}{|l|l|l|}
\hline Density & Melting point & $\begin{array}{l}\text { Thermal } \\
\text { expansion }\end{array}$ \\
\hline $1.38 \mathrm{~g} / \mathrm{cm}^{3}$ & $260^{\circ} \mathrm{C}$ & $6-7 /{ }^{\circ} \mathrm{C}$ \\
\hline
\end{tabular}

\section{Mix design for concrete}

Table 3. Mix Design details (for $1 \mathrm{~m}^{3}$ )

\begin{tabular}{|l|l|l|l|l|}
\hline $\begin{array}{l}\text { Cemen } \\
\text { t }\end{array}$ & $\begin{array}{l}\text { Fine } \\
\text { Aggregat } \\
\text { e }\end{array}$ & $\begin{array}{l}\text { Coarse } \\
\text { Aggregat } \\
\text { e }\end{array}$ & $\begin{array}{l}\text { Wate } \\
\mathbf{r}\end{array}$ & $\begin{array}{l}\text { Slump(mm } \\
\text { ) }\end{array}$ \\
\hline $370 \mathrm{~kg}$ & $687.8 \mathrm{~kg}$ & $1188.5 \mathrm{~kg}$ & 168 lit & $75-100$ \\
\hline
\end{tabular}

\section{Compressive strength and workability studies}

Casted the cubes of $100 \mathrm{~mm}$ size with different percentage of plastics individually. The compressive strengths of $100 \mathrm{~mm}$ cubes converted into $150 \mathrm{~mm}$ cube of compressive strength. Compare the workability and compressive strength of PET and PP as fine replacement in concrete with conventional concrete.

\subsubsection{Studies on workability and compressive strength of Polypropylene}

Table 4. slump test values with different percentage of Polypropylene

\begin{tabular}{|l|l|l|l|l|}
\hline $\begin{array}{l}\text { Plastic } \\
\text { Percentage }\end{array}$ & $0 \%$ & $5 \%$ & $10 \%$ & $15 \%$ \\
\hline Slump(mm) & 100 & 90 & 150 & 110 \\
\hline
\end{tabular}

Table 5. Compressive Strength results of different percentage of Polypropylene

\begin{tabular}{|l|l|l|l|}
\hline $\begin{array}{l}\text { Plastic } \\
\text { Replacement } \\
(\%)\end{array}$ & $\begin{array}{l}\text { 3 Days } \\
\text { MPa }\end{array}$ & $\begin{array}{l}\text { 7 Days } \\
\text { MPa }\end{array}$ & $\begin{array}{l}\text { 28 Days } \\
\text { MPa }\end{array}$ \\
\hline $0 \%$ & 22.5 & 31.5 & 38.7 \\
\hline $5 \%$ & 23.4 & 30.6 & 38.3 \\
\hline $10 \%$ & 21.6 & 27.9 & 33.3 \\
\hline $15 \%$ & 18.9 & 21.6 & 27.9 \\
\hline
\end{tabular}

Workability of Polypropylene concrete increases beyond $5 \%$ (shear slump). The compressive strength decreases beyond 5\% of Polypropylene replacement as fine.

\subsubsection{Workability and compressive strength results of Polyethylene Terephthalate}

Table 6. Slump values

\begin{tabular}{|l|l|l|l|l|}
\hline $\begin{array}{l}\text { Plastic } \\
\text { Percentage }\end{array}$ & $0 \%$ & $5 \%$ & $10 \%$ & $15 \%$ \\
\hline
\end{tabular}




\begin{tabular}{|l|l|l|l|l|}
\hline Slump(mm) & 100 & 90 & 70 & 50 \\
\hline
\end{tabular}

Table 7. Compressive Strength values of different percentage of Polyethylene Terephthalate.

\begin{tabular}{|l|l|l|l|}
\hline $\begin{array}{l}\text { Plastic } \\
\text { Replacement } \\
(\%)\end{array}$ & $\begin{array}{l}\text { 3 Days } \\
\text { MPa }\end{array}$ & $\begin{array}{l}\text { 7 Days } \\
\text { MPa }\end{array}$ & $\begin{array}{l}\text { 28 Days } \\
\text { MPa }\end{array}$ \\
\hline $0 \%$ & 22.5 & 31.5 & 38.7 \\
\hline $5 \%$ & 26.1 & 34.2 & 39.6 \\
\hline $10 \%$ & 25.2 & 32.4 & 38.2 \\
\hline $15 \%$ & 20.7 & 24.3 & 27 \\
\hline
\end{tabular}

Here the plastic content increases the compressive strength values decreases beyond $10 \%$ because the excess plastic content not binding properly in concrete leads to decreases the compressive strength values and also the excess plastic can obstruct the flow of the concrete. So, the workability and compressive strength values decreases beyond $10 \%$

\section{Results}

\subsection{Test results of concrete with Polypropylene}

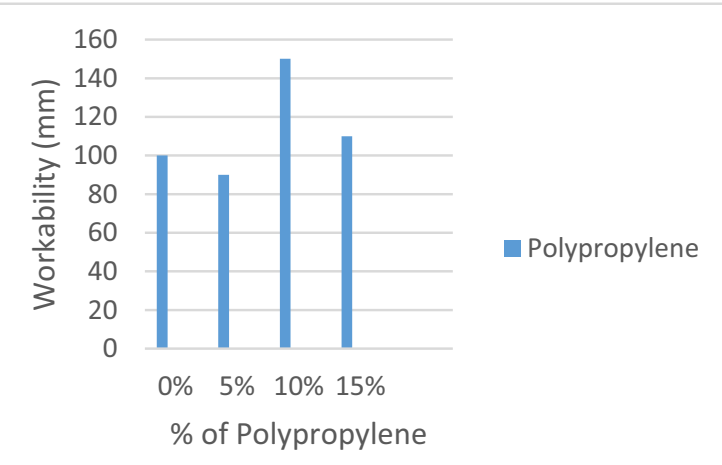

Fig. 1. shows the variation of workability of concrete with Polypropylene.

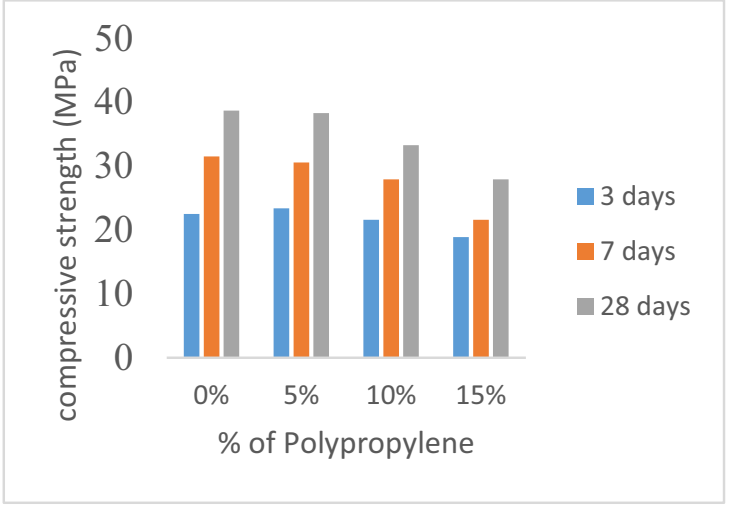

Fig. 2. Shows Compressive Strength of concrete with polypropylene.

\subsection{Test results of concrete with Polyethylene Terephthalate}

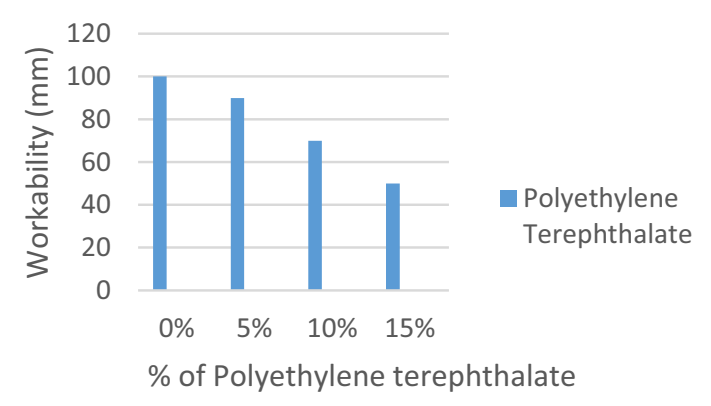

Fig. 3. Shows workability of concrete with Polyethylene Terephthalate.

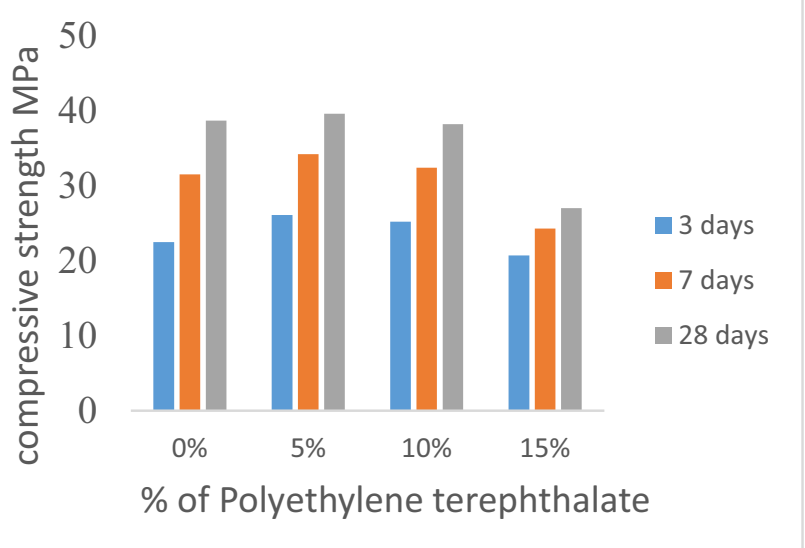

Fig. 4. Shows compressive strength with polyethylene Terephthalate. 


\section{Conclusions}

The concrete with plastic can influence the properties of concrete like workability and compressive strength. The plastic content increases, workability and compressive strength decreases. Voids increases then volume of the concrete increases due to the increment of plastic content. The concrete volume is increases as replacement of PET and $\mathrm{PP}$ in concrete as a fine aggregate that results in decreases the density of concrete because of its different volume occupation of plastics and sand. The concrete with $10 \%$ PET has given better results in compressive strength and workability, where as PP has given good results at 5\% replacement on workability and compressive strength. Therefore, it is concluded that an optimum replacement of fine aggregate with PET is $10 \%$ and $\mathrm{PP}$ is $5 \%$.

\section{References}

1. Lokeshwari, M., et al. Int. Res. J of Eng. and tech. (IRJET) (2019): 1-5.

2. Saxena, Rajat, et.al., Scientia Iranica,27.1 (2020):1-9

3. Asadi, S. S.." Int J Civ Eng Technol. 8.1 (2017): 558-68.

4. Gopi, K. Sai, and T. Srinivas. E3S Web of Conferences. Vol. 184. EDP Sciences, 2020.

5. Karthik Rao, R., Bobba, P.B., Suresh Kumar, T., Kosaraju, S. Materials Today: Proceedings, 26, pp. 3085-3089, 2019

6. Almeshal, Ibrahim, et al. $J$ of Mat. Res. and Tech. 9.3 (2020): 4631-4643.

7. T.Srinivas and M. Abinay Raj, Int. J. of Eng.and Adv. Tech. (IJEAT), ISSN: 2249 - 8958, Volume-8 Issue-6 (2019)

8. T.srinivas and P. Manoj Anand, Int. J. of Innov. Tech. and Explor. Eng.g (IJITEE), ISSN: 22783075, Volume-8 Issue-12 (2019)

9. T.Srinivas and G. Sukesh Reddy, Int. J. of Eng.and Adv. Tech. (IJEAT), ISSN: 2249 8958, Volume-9 Issue-1 (2019)

10. T.Srinivas and R. N. Koushik, Int. J. of Innov. Tech. and Explor. Eng.g (IJITEE), ISSN: 22783075, Volume-8 Issue-12 (2019), PP 112-117.
11. K. Sai Gopi, Dr. T. Srinivas and S. P. Raju V, E3S Web of Conferences ICMED 184, 01084GRIET, 28-29 February, https://doi.org/10.1051/e3sconf/2020184011084 (2020)

12. Jagannadha Kumar, M.V., Jagannadha Rao, K., Dean Kumar, B., Srinivasa Reddy, V., Int. J. of Civil Eng. and Tech., 9(7), pp. 1133-1141 (2018)

13. Ganta, J.K., Seshagiri Rao, M.V., Mousavi, S.S., Srinivasa Reddy, V., Bhojaraju, C., Structures 28, pp. 956-972 (2020)

14. Naidu, K.S.S.T., Rao, M.V.S., Reddy, V.S., Int. J. of Innov. Tech. and Explor. Eng.g (IJITEE), 8(9 Special Issue 2), pp. 641-642 (2019)

15. Chandana Priya, C., Seshagiri Rao, M.V., Srinivasa Reddy, V., Int. J. of Civil Eng. and Tech., 9(11), pp. 2218-2225 (2018)

16. Satya Sai Trimurty Naidu, K., Seshagiri Rao, M.V., Srinivasa Reddy, V., Int. J. of Civil Eng. and Tech., 9(11), pp. 2383-2393 (2018)

17. Raju, N.A., Suresh Kumar, T. International Journal of Innovative Technology and Exploring Engineering, 8(11), pp. 3860-3864, 2019

18. Supriya, Y., Srinivasa Reddy, V., Seshagiri Rao, M.V., Shrihari, S., Int. J. of Rec. Tech. and Engi., 8(3), pp. 5381-5385 (2019)

19. Kotkunde, N., Krishna, G., Shenoy, S.K., Gupta, A.K., Singh, S.K. International Journal of Material Forming, 10 (2), pp. 255-266 (2017)

20. Govardhan, D., Kumar, A.C.S., Murti, K.G.K., Madhusudhan Reddy, G. Materials and Design, 36, pp. 206-214. (2012)

21. Kumar, P., Singhal, A., Mehta, S., Mittal, A. Journal of Real-Time Image Processing, 11 (1), pp. 93-109. (2016)

22. Raghunadha Reddy, T., Vishnu Vardhan, B., Vijayapal Reddy, P. International Journal of Applied Engineering Research, 11 (5), pp. 30923102 (2016)

23. M. Kavitha, P. B. Bobba and D. Prasad, 2016 IEEE 6th International Conference on Power Systems (ICPS), 2016, pp. 1-6

24. Hussaini, S.M., Krishna, G., Gupta, A.K., Singh, S.K. Journal of Manufacturing Processes, 18, pp. 151-158 (2015) 